\title{
JEWS AND THE ROMAN ARMY: PERCEPTIONS AND REALITIES ${ }^{1}$
}

\author{
Jonathan P. Roth
}

Scholars, including military historians, often project the conventions of Talmudic, or even modern, Judaism back into previous periods. This is particularly true in general assumptions about Jews in the military

\footnotetext{
1 This note contains a select bibliography, some titles of which will be cited in the following footnotes.

S. Applebaum, 'Three Roman Soldiers of Probably Jewish Origin,' in M. Rozelaar and B. Shimron, eds., Commentationes ad antiquitatem classicam pertinentes in memoriam B. Katz (Tel Aviv 1970).

_ ' 'Ein Targhuna,' in S. Applebaum, Judaea in Hellenistic and Roman Times: Historical and Archaeological Essays (Leiden 1989), 66-69.

B. Bar-Kochva, The Seleucid Army: Organization and Tactics in the Great Campaigns (Cambridge 1976).

P. Bilde, Flavius Fosephus between Ferusalem and Rome (Sheffield 1988).

M. Gichon, 'Aspects of a Roman Army in War According to the Bellum Fudaicum of Josephus', in D. Kennedy and Ph. Freeman, eds., The Defence of the Roman and Byzantine East I. BAR International Series 297, I (Oxford 1986), 287-310.
}

A. Goldsworthy, 'Community Under Pressure: The Roman Army at the Siege of Jerusalem,' in A. Goldsworthy and I. Haynes, The Roman Army as a Community. Journal of Roman Archaeology Supplemental Series 34 (Portsmouth RI 1999).

R. González Salinero, 'El servicio militar de los judíos en el ejército romano,' Aquila Legionis 4 (Madrid 2003), 45-91.

M.H. Gracey, 'The Armies of the Judaean Client Kings,' in D. Kennedy and Ph. Freeman, eds., The Defence of the Roman and Byzantine East I. BAR International Series 297, I (Oxford 1986).

J. Helgeland, 'Christians and the Roman Army AD 173-337,' Church History 43/2 (June 1974), 149-163.

B. Isaac, 'Reflections on the Roman Army in the East,' in D. Kennedy and Ph. Freeman, eds., The Defence of the Roman and Byzantine East I. BAR International Series 297, I (Oxford 1986), 383-395.

C.P. Jones, 'Egypt and Judaea under Vespasian,' Historia 46.2 (1997), 249-253.

J. Lesquier, Les institutions militaire de l'Egypte sous les Lagides (Paris 1911).

M. Mor, 'The Roman Army in Eretz-Israel in the Years 70-132,' in D. Kennedy and $\mathrm{Ph}$. Freeman, eds., The Defence of the Roman and Byzantine East I. BAR International Series 297, I (Oxford 1986), 575-602.

J. Price, 'The Enigma of Philip ben Jakimos,' Historia 40.1 (1991), 77-94. , Ferusalem Under Siege: The Collapse of the Jewish State 66-70 CE (Leiden 1992).

J. Roth, The Logistics of the Roman Army in the Jewish War (dissertation Columbia University, New York 1991).

D.B. Saddington, 'Armed forces in the New Testament,' in New International Dictionary of Biblical Archaeology (Michigan 1983), 68-69. 
and Jewish attitudes towards the Romans. In discussing this issue, it is important to note that the meaning of the terms 'Romans' and 'Jews' is not always clear, and was used variously and loosely in antiquity as well as today. In addition, the terminology shifted over time. Much of ancient, and modern ethnic terminology refers to region or language, but not without ambiguity. When the Romans referred to Syrians, for example, they might mean the inhabitants of Syria, whether Greek, Aramaic or even Latin speaking, or they might mean anyone who spoke Syrian, even in the first century a common way of referring to Aramaic.

On the other hand, while 'Roman' could be an ethnic term, it also had a political meaning. We know of many Jews who had Roman citizenship, Herod, Paul and Josephus are only the most famous examples. Tiberius Julius Alexander was not only a citizen, but also held high rank in the military. He is often mentioned in our sources without any reference to his Jewishness, and almost certainly would have been called a Roman in some contexts. Josephus says he "did not follow in the religion of his country" but this might reflect a doctrinal dispute rather than an objective observation. In any case, Alexander's lack of piety did not make him any less Jewish.

A Hebrew name is a good indicator of Jewishness in the pre-Christian period, but a Greek or Latin name certainly does not exclude the possibility. We know of many Jewish individuals with Greek and Latin names from the Talmud, the New Testament and inscriptions. Indeed, the Jewish catacombs in Rome, and elsewhere, are full of inscriptions with Latin names. We find many individuals in the Herodian, or Jewish royal, army who have Latin names. Examples are Rufus the commander of the Royal Cavalry, ${ }^{3}$ Volumnius a military tribune ${ }^{4}$ and Aebutius a decurion. ${ }^{5}$ The general assumption has been that they are ethnic Romans, serving in Herod's army, and this is certainly possible. It is also possible, however, and in some cases more likely, that they are Jews with Latin names. While Herod and his successors certainly used Roman officers, we should not assume that there were no Jewish ones.

I. Shatzman, 'The Integration of Judaea into the Roman Empire,' Scripta Classica Israelica 18 (1999), 49-84.

M.P. Speidel, 'The Roman Army in Judaea under the Procurators,' Ancient Society 13/14 (1982/3), 233-240.

E.G. Turner, 'Tiberius Iulius Alexander,' Journal of Roman Studies 44 (1954), 54-64.

${ }^{2}$ Af 20.100, see Turner (1954).

${ }^{3}$ BJ 2.52.

${ }^{4}$ Bf 1.535, Af 16.332.

${ }^{5}$ BJ 4.36. 
While the Jewish king was technically commander-in-chief, and sometimes actually led the army, there was a commander of all Jewish royal military forces called the strategos. In his discussion of the revolt of $4 \mathrm{BCE}$, Josephus mentions a general (strategos) being sent into the temple to negotiate with the rebels. Thackeray mused that this might be the sagan or Temple Captain. This position, however, was a fiction of the New Testament, as will be discussed below. Instead, the strategos mentioned is doubtless the commander-in-chief of Archelaus' armies, ${ }^{6}$ an individual named Gratus. ${ }^{7}$ How could Archelaus have sent a Roman into the Temple? This strongly suggests that Gratus was a Jew with a Latin name. Aequus Modius, an important, if enigmatic, figure in the Jewish Royal Army attracts attention. At first glance it seems to mean 'Fair Measure,' which might be a nickname: he could have served as a quartermaster. Alternatively, it might reflect the Roman nomen Modius and cognomen Aequus. ${ }^{8}$ Modius might also be a calque on a Jewish name such as Omri or Gomer. In any case, he may well have been a Jewish soldier with a Latin name. Another officer in a Jewish unit is named Sulla. It seems an unlikely cognomen for a Roman of the late first century, but makes sense as a nickname or cognomen for a Jew. ${ }^{9}$

Samaritans float ambiguously from Jewish to non-Jewish in both the ancient and the modern mind. As Roman soldiers, they are generally seen as non-Jews, although in fact they were virtually identical to Jews in religion, language and custom. Josephus tells us that 3,000 Samaritans in Herod's army stayed loyal during the uprising of $4 \mathrm{BCE}$ and since Josephus later notes that the garrison of Judea was made up of five cohorts infantry and an ala or wing of cavalry, it makes sense to see these as the same force. One of these Samaritan cohorts and the cavalry ala are attested in inscriptions. ${ }^{10}$ Indeed, there would be no reason to think there were any non-Samaritans in the Roman garrison of Judea were it not for reference to them in the New Testament. An Italian cohort is mentioned in Acts of the Apostles as the unit of the first Gentile convert to Christianity, the centurion Cornelius, and the Augustan Cohort, to which belonged the centurion Julius, who escorts Paul to

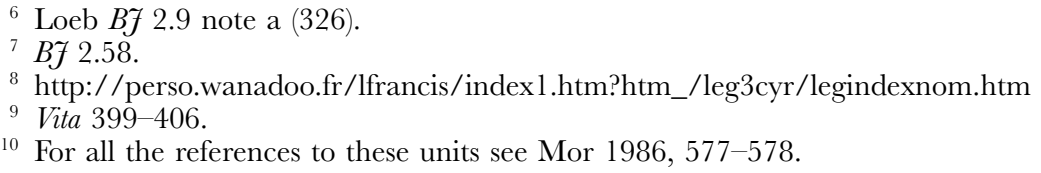

${ }^{10}$ For all the references to these units see Mor 1986, 577-578. 
Rome. In an influential article, Michael Speidel showed that it was possible that these units did exist. ${ }^{11}$ The Augustan cohort is attested in an inscription dating to the $80 \mathrm{~s} \mathrm{CE} .^{12}$ This unit, however, was part of Agrippa II's army, and though as Speidel notes, it is certainly possible that a Roman unit could serve in the army of a client king, it is equally possible that this is a Herodian unit, with either a Roman officer or a Jewish (i.e. native) officer with a Latin name. Thus the existence of an Augustan cohort in the Roman garrison of Judea is far from proven.

As for the Italian cohort, Speidel claims that it is a cohors civium Romanorum. Speidel actually identifies a cohors II Italica c.R. that was in Syria as early as $63 \mathrm{CE}$, though it moved to Noricum before the Jewish War. As he argues, this unit could be the one called the speire tes kaloumenes Italike in the New Testament's Acts of the Apostles. ${ }^{13}$ The unit is not mentioned by Josephus nor is there epigraphical evidence for it at Caesarea or anywhere in Judea. It is possible that the unit did not exist or was a later Syrian unit displaced to a different place and earlier time. The historicity of Acts is a complex issue, but from a military historical perspective, the author of the work seems uninformed about the security situation in Jesus' Palestine. For example, he refers to a strategos tou hierou usually translated 'Captain of the Temple' although 'General of the Temple' would be more literal. This officer commands a paramilitary force that seems to act like police: in Acts 4.1, the 'Captain' along with the 'priests' and the Sadducees arrest Peter and John and place them under guard (eis teresin). In the next chapter, Peter is also arrested. ${ }^{14}$ The arrest is actually made by the high priest, and the apostle is put in prison (desmoterion). 'Officers' (hyperetai) and 'guards' (phylakes) find him missing, and the Captain of the Temple among others, is perplexed.

Josephus makes no mention of such an official or of any Temple Police either in his description of the Temple or in any other part of his writings. ${ }^{15}$ Given Josephus' knowledge and interests, this is a powerful argument from silence. The Middoth, a tractate in the Mishnah Kedoshim, which concerns the temple, describes these guards. ${ }^{16}$ The Middoth, however, suggests that this Temple Guard was a nominal one, made

\footnotetext{
Speidel (1982/3), Saddington (1982) and Mor (1986) accept Speidel's conclusion.

AE 1925.121, cf. IGR 3.1136 (Hit), Speidel (1982/3), 238.

Acts 10:1.

Acts 5:17ff.

See especially Bf 5.22 where one would expect such a reference.

${ }^{6}$ Mish. Ked. 10.1.1-2, 9.
} 
up only of three Priests and 21 Assistant Priests, who were stationed at various parts of the Temple as a sort of ceremonial watch. The commander does not have the quasi-military title sagan, who is in fact another Temple official, in charge of ritual, but is called only The Overseer of the Temple Mount (ish har ha-bayit). The Middoth gives the source for its description: Eliezar bar Jacob, who was one of the Tannaim of the Second generation (along with Gamaliel II) and was a disciple of Johannon ben Zakkai. He was probably a boy or a young man during the Jewish War. ${ }^{17}$ It is clear from his description, that the temple guards were by no means a police or security force, but only a ritual guard. Indeed, there is no indication that they were armed. It is noteworthy that Jerome translates strategos tou hierou as magistratus templi, not with a military term. The entire presentation of this religious police force is probably fictional. The way in which Acts completely misconstrues the Temple Guard suggests that its author was far from a eyewitness and indeed was poorly informed about the realities of first century Palestine. The same can be said of many military aspects of the New Testament. At very least we should conclude that military historians should use the New Testament with extreme caution.

If we accept that all of the forces in Judea before the Jewish War were Samaritans, it puts several incidents mentioned by Josephus in a different light. At one point, a 'Roman' soldier raised his tunic and exposes himself to a Jewish crowd in the Temple courtyard, causing a riot. If we see this soldier as a Samaritan, then this anti-Jewish act takes on a completely different significance. When the revolt first breaks out, a cohort is trapped in the Antonia fortress. The commander negotiates a surrender, but the rebels break it and massacre the soldiers. We might well view this as anti-Samaritan, not anti-Roman, act. It is noteworthy that the unit's commander, who was certainly a Roman, was humiliated, but spared.

Although little attention has been paid to it, we are actually remarkably well informed about the organization of the Herodian military forces. ${ }^{18}$ When Herod built up his army, he probably organized, trained and armed them in the Roman fashion. Josephus refers to five Roman cohorts (speiras) and five Jewish ones operating together. ${ }^{19}$ It is true that

17 Another Eliezar B. Jacob lived later and was a disciple of R. Akiba.

18 Contra Price (1991), 77 note 2, See Gracey (1986).

19 Bf 1.301. 
Herod's bodyguard was made up of Gauls, Thracians and Germans. ${ }^{20}$ These units, however, were probably relatively small, perhaps a thousand men in total at most, and in any case, we hear nothing of them after Herod's funeral. They were probably disbanded, either by Archelaus or by the Romans when they took control in 6 cE. The bulk of Herod's army was Jewish, in some sense of the word.

Like all Hellenistic forces, the mainstay of the Herodian army consisted of soldiers in military settlements. The first, and most important, of Herod's military settlement was at Sebaste, which initially consisted of 6,000 men. ${ }^{21}$ Jewish sources sometimes scornfully refer to them at Cuthaeans (that is, Babylonians) or even Kittim, but there is no reason to think that the Samaritan forces in Herodian service were pagans and not monotheists. Other military settlements were unambiguously Jewish. A unit of Babylonian Jewish horse-archers was that at Bathyra, in Batanea (Bashan). Josephus claims in $A \mathcal{f}$ that by the time of the Jewish revolt, the Bathyran unit was as large as the rest of King Agrippa's army combined..$^{22}$ There was an Idumaean settlement of 2,000 men, but we do not know of its exact location. The Idumeans were forcibly converted to Judaism by the Hasmoneans, but while we are not wellinformed, there is no reason to doubt that Jewish belief and ritual was widespread among the Idumean soldiers in Herodian service. We hear of three other military settlements: at Esbonitis (Heshbon), east of the Dead Sea in Perea, an area which apparently was mainly inhabited by Jews, ${ }^{23}$ at Gaba, north of Mount Carmel, ${ }^{24}$ and at Trachonitis (Heb. Argob), located to the east of the Jordan. The latter unit was made up of 3,000 men and was probably stationed at the fort whose remains are at 'Ein Targhuna today. ${ }^{25}$ According to Josephus, it was destroyed in the revolt of $10-9 \mathrm{BG},{ }^{26}$ but we hear again of forces from Trachonitis, specifically archers, in the revolt of $4 \mathrm{BC}$. This is significant, as it sug-

${ }^{20}$ Af 16.198-199; Bf 1.397, 672.

${ }^{21}$ Bf 1.403, 2.55, Af 15.293, 17.266. Sebaste was a refounding of the colony of Samaria, established as a military colony by Alexander himself. It played an important role in Seleucid resistance to the Hasmoneans, and was probably destroyed by Alexander Jannaeus (Af 375-378).

${ }^{22}$ Af 17.3.

${ }^{23}$ Af 15.294.

${ }^{24}$ Af 15.294, Bf 2.36. Its exact location is unknown.

${ }_{25}$ Af 16.271, 295, Applebaum (1989), 67-68. Applebaum's suggestion that the unit, along with the Bathyran archers, was moved to Libya by Augustus, has little to recommend it.

${ }^{26}$ Af 16.292. 
gests that such military colonies might be reestablished when destroyed. There is the question of militia. ${ }^{27}$ During the Jewish War, Simon bar Giora raises his forces, according to Josephus, first from freed slaves and the poor (poneroi). ${ }^{28}$ Subsequently, however, he draws from the "citizen levy (demotikon ... oligon) who obeyed him like a king." 29 This may refer to Jewish property-owners subject to military service in the Greek hoplite style.

Jewish military units did not just defend Palestine in the Roman interest. Jewish forces took part in the Civil War, providing troops for Caesar's Alexandrine War for example, and in Roman expeditions in the imperial period. Forces of Agrippa II took part in the Bosporan campaign and in the ill-fated invasion of the Arabian peninsula under Aelius Gallus. ${ }^{30}$ We happen to know of these examples, but we should not reject the notion that the auxiliary troops of many, if not most of the Roman eastern campaigns in the Late Republic and early empire included Jewish troops fighting for Rome. It is certain that Jewish forces played a part, small but nonetheless significant, in the suppression of the Jewish Revolt of 66-70, a role that is generally completely ignored.

When the uprising threatened, the Jewish King Agrippa II sent Philip, called a 'strategos' along with a 'hipparch' named Darius and 2,000 cavalry, including Bathyrans to Jerusalem. ${ }^{31}$ It is noteworthy that the Romans seem to have relied primarily on the forces of the local client king for security. While the Herodians sent 2,000 men, the Romans had only a single cohort, 500 men, in the Holy City. Agrippa II had moved forces into the Galilee in mid-March, long before Cestius Gallus, the governor of Syria set out for Jerusalem with his legions. Agrippa is clearly acting aggressively and decisively in the Roman interests. The Jewish Royal Army, under the command of Modius Aequus, besieged Gamala in the Golan. ${ }^{32}$ They kept this strategic city blockaded for seven months, before being relieved by Roman forces. This no doubt represented the bulk of the Herodian forces, including the Babylonian archers. Another royal Jewish force was sent under a 'decurion' (dekadarchos) named Aebutius to engage Josephus' forces at Simonia, west of Nazareth. ${ }^{33}$

27 Gracey (1986), 317.

Bf 4.508.

Bך 4.510 .

Af 16.27ff., Strabo, Geogr. 16.4.22ff.

BJ 2.17.4.

Bf 4.11, 83.

33 Bf 4.36 . 
Josephus gives the size of this force as 100 cavalry, 200 infantry and an unknown number of 'allies,' symmachoi, from Gaba. This town, of course, was the site of a Herodian military settlement, which is clearly still functioning. The 300 'regulars' certainly represent the unit stationed there, but who are these 'allies'? Josephus may be referring to other Jews in the settlement, who did not owe military service, but who volunteered to fight for their king. It is impossible to be sure, but this might be a clue to a pro-Roman feeling among some Jews. Josephus might be expected to mention such loyalty to Rome, but it might have been embarrassing, considering that he was still in rebellion at the time and fighting these very same individuals. Indeed, the story is omitted entirely in the BJ. In any case, Josephus force of 2,000 was defeated at the cost of only three royal Jewish soldiers, so the Jewish Royal Army was clearly an effective force. ${ }^{34}$ Josephus mentions a third pro-Roman Jewish force, the royal bodyguard, which also fought in Galilee under the command of its captain, Sulla. Josephus does not mention the size of this force, but it was probably around 500 men. The reason for this hesitancy is that Sulla's small force beat 5,000 of Josephus' men. Agrippa II's role in the rebellion was important. He held onto Western Galilee, and although most of Eastern Galilee remained in revolt, he neutralized the important base at Gamala.

Jewish Royal forces are not mentioned in any of the operations leading up to the siege of Jerusalem, but this does not mean, of course, that they were not present. Josephus does mention the presence of both high-ranking Jewish officers and Jewish Royal forces at the siege of Jerusalem..$^{35}$ Tiberius Julius Alexander was present, and in fact may have been the de facto commander of the Roman forces. Although, as noted above, his Jewishness is often denigrated or ignored, he came from the most notable Jewish family in Egypt and was certainly Jewish in the ethnic sense at least. Josephus notes that the client kings' armies, including the Jewish Royal army, made up the vanguard of Titus' army as it advanced on Jerusalem.

We cannot say exactly how the Jewish contribution to the Roman war effort was. Assuming that the Herodian army had around 3,000 to 5,000 and this might well be an underestimate, and noting that the size of the Roman deployment changed over time, from a low of about 35,000 to

34 Vita 114-118.

${ }^{35}$ Bf 5.42ff. 
a high of some 70,000, we see that this Jewish contribution varied from some $5 \%$ to $10 \%$ of the total Roman force. This was certainly a significant factor. If we add in the Samaritan cohorts, some 3,000 men, and call them 'Jewish' then the total might rise to as high as $20 \%$ at some points in the conflict. That these forces were present throughout the war is proven by the fact that Vespasian removed them only after the end of the conflict. ${ }^{36}$ In addition, Jewish leaders such as Agrippa II and Tiberius Julius Alexander provided important guidance and advice. The latter might well have been the strategic planner of the Roman campaign.

It is true that Jews were exempted from conscription and auxiliary units could not be raised in Judea. The assumption is made that this was for religious reasons. This view is quite widely held. The first such exemption was given by the Pompeian Lentulus Crus in 49 BGE, and does seem to have been given for religious reasons. ${ }^{37}$ Nevertheless, it is likely that Jews were exempted from military service, first by Julius Caesar and then by others, not primarily due to Roman sensitivity to their religion, but due to Jewish loyalty and contributions to the Gaesarian cause. The freedom from conscription did not mean that Jews did not fight: rather they did so on a voluntary basis. The importance of the Jewish contribution is illustrated in the Alexandrine War, in which Caesar almost died. Jews contributed a force of 1,500 to 3,000 (depending on the source). ${ }^{38}$ Caesar had only 5,000 men, so this was a very significant contribution in either case. Josephus reports that Antipater, Herod's father, was personally responsible for the taking of Pelusium.

The exemption from recruiting auxiliary forces in Judea seems to have been technically recognized, in that no cohort or ala is called fudaeorum, until the Late Empire. This does not mean, however, that these units did not have Jews in them. The Samaritan cohorts had the same religious scruples and taboos as the Jews, which shows that the exemption was based primarily on national, and not religious grounds. It also indicates that Jews could accommodate doing military service in the Roman Army. In addition, the auxiliary units stationed in the country after 70 must have begun recruiting locally, as did those in other parts of the empire. It is highly likely, therefore, that many Jews, in the

\footnotetext{
${ }^{36}$ Af 19.363.

37 Af 14.240 .

${ }^{38}$ Af 14.8.1.
} 
regional, ethnic and religious sense of the word, served in these units in the centuries they occupied the country. Indeed, the changing of the name of the province to Palaestina, may in part be due to a wish to continue to honor, technically, Caesar's exemption, without giving up local recruitment.

The exemption was not always honored. Tiberius drafted 4,000 Jews into military service to fight brigands in Sardinia. ${ }^{39}$ There is no suggestion that they fought in all-Jewish units, they would have served as replacements (supplementum). This remained the exception of course, but simply because Jews were exempted from conscription, does not mean that they did not serve in the Roman military as volunteers. In an article published in 1970, Shimon Applebaum identified three Roman soldiers of probable Jewish origin, and argued that there were probably many others, who remain unidentified. In a recent article, Raúl González Salinero, has found scores of possible Jewish Roman soldiers. ${ }^{40}$ Further work is necessary, both to discuss these individuals on a case-by-base basis, and indeed to search for more possible candidates. ${ }^{41}$ It is striking that scholars do not find it strange to have Christians in pagan Roman military units, and yet find it difficult to believe Jews were present. ${ }^{42}$

The key issue here is the identification of Jews. Most soldiers are known only by their names, and these would not necessarily have been different. Although some Jewish names are distinct, many are not, and even this would have been hidden by the translation of names in Latin or Greek versions. Most focus has been on Jewish soldiers who spoke Aramaic or Greek. In the west, however, there would have been an increasing population of Latin speaking Jews, who would have been difficult to distinguish from non-Jewish Latin speakers. Another source of Jewish recruits that might remain escape notice would be Jewish Arabs. Soldiers with Arabic names are well-known, particularly due to the Dura-Europus rosters. Although a synagogue was found at Dura-Europus, the possibility of some of these 'Arabs' being Jews is not often considered.

Anyone with a cursory knowledge of the rise of Islam knows of the existence of Jewish tribes in Arabia. Three of these tribes, the Banu

\footnotetext{
39 Tacitus, Annales 2.85.

40 Applebaum (1970), González Salinero (2003).

${ }^{41}$ For example, the Castricius, husband of Julia, who was buried in the Jewish Catacomb on the Via Appia in Rome.

${ }^{42}$ Helgeland (1974).
} 
Qaynuqa, the Banu-l Nadir and the Banu Qu'aryza, lived in Yathrib, later known as Medina. They were clearly martial and participated on both sides of Mohammed's wars, playing a key role in the Battle of Badr and other important early Muslim fights. We know of these Jewish tribes through the Koran and Hadith, but there were probably other Jewish Arab tribes around the peninsula and elsewhere. How old are these tribes? Could Judaism, like Christianity, have spread to the northern Arabian tribes as early as the late Roman period? It is not only possible, but likely. The Federate Ghassanids, who guarded Rome's southeastern frontiers for centuries, are called Christians, and indeed their leaders were. Yet the Ghassanids were a confederation (the term Saracen is probably derived from the Aramaic for confederation), and thus it is possible that Jewish Arab tribes made up part of the federate forces.

In the Fifth Century, the Christian Empire prohibited Jews from serving in the Roman military. The first of these laws may have been promulgated by Honorius in $404 \mathrm{CE}$ : he removed Jews either from the military or from the agents in rebus, depending on the interpretation of the law. ${ }^{43}$ Jerome in his Commentary on Isaiah (408-410) writes that Jews could not serve as soldiers in his day, implying that they could do so in an earlier age. ${ }^{44}$ Whether or not Honorius had already banned Jews from the army, and found it necessary to issue a more comprehensive decree, or if he was expanding a ban to include the army, in 418 he issued the following: ${ }^{45}$

Entrance into the military service from any other occupation is denied those who are living in the Jewish faith. Therefore any Jews who are either engaged in government service or in the imperial army are permitted the grace of completing their terms of office and of terminating their enlistments (since such persons are really more ignorant than unfriendly), but in the future the grace we have now granted a few will not be continued. We decree, moreover, that those devoted to the perversity of this Jewish nation, who are proved to have entered the armed forces, shall be deprived of their honor at once, being allowed no sufferance for past good deeds.

It is difficult to imagine that these decrees do not deal with a very real presence of Jews in the Roman military. González Salinero discusses the enigmatic Late Roman units called Regii Emeseni Iudaei, which, he

${ }^{43}$ CTh. 16.8.16; 22/4/404.

${ }^{44}$ Jerome, Comm. in Es. II.3.

${ }^{45}$ CTh. 16.8.24; 10/3/418. 
argues, may well represent all-Jewish units, as well as individuals who served in the Late Roman army. ${ }^{46}$

This talk has only touched on a number of difficult and controversial subjects. The evidence for Jewish involvement with the Roman military as allies is clear if fragmentary. Evidence for Jews serving directly in the Roman military is growing. Jews in a pre-Christian world felt quite comfortable in a military context, serving foreigners. Jews as often admired the Roman military, enough to join it in some cases, as they resented and opposed it.

${ }^{46}$ González Salinero (2003), 63ff. 